\title{
AGE-RELATED EFFECTS OF ST THOMAS' HOSPITAL CARDIOPLEGIC SOLUTION ON ISOLATED CARDIOMYOCYTE CELL VOLUME
}

Jeffrey S. Danetz, MD

Henry F. Clemo, MD, $\mathrm{PhD}^{\mathrm{b}, \mathrm{c}}$

Ruth D. Davies ${ }^{\mathrm{c}}$

Richard P. Embrey, MD

Ralph J. Damiano, Jr, MD ${ }^{\mathrm{d}}$

Clive M. Baumgarten, $\mathrm{PhD}^{\mathrm{c}}$
Objectives: We tested the hypothesis that neonatal cells are more sensitive to cardioplegia-induced cell swelling than more mature cells and spontaneous swelling in the absence of ischemia can be prevented by cardioplegia with a physiologic $\mathrm{KCl}$ product. Methods: Cell volumes of isolated ventricular myocytes from neonatal (3-5 days), intermediate (10-13 days), and adult (>6 weeks) rabbits were measured by digital video microscopy. After equilibration in $37^{\circ} \mathrm{C}$ physiologic solution, cells were suprafused with $37^{\circ} \mathrm{C}$ or $9^{\circ} \mathrm{C} \mathrm{St}$ Thomas' Hospital solution (standard or low $\mathrm{Cl}^{-}$) or $9^{\circ} \mathrm{C}$ physiologic solution followed by reperfusion with $37^{\circ} \mathrm{C}$ physiologic solution. Results: Neonatal cells swelled 16.2\% $\pm 1.8 \%(P<$ $.01)$ in $37^{\circ} \mathrm{C}$ St Thomas' Hospital solution and recovered during reperfusion, whereas more mature cells maintained constant volume. In contrast, $9^{\circ} \mathrm{C}$ St Thomas' Hospital solution caused significant age-dependent swelling (neonatal, $16.8 \% \pm 1.5 \%$; intermediate, $8.6 \% \pm 2.1 \%$; adult, $5.6 \% \pm 1.1 \%$ ). In contrast to more mature cells, neonatal cells remained significantly edematous throughout reperfusion $(8.1 \% \pm$ $1.5 \%)$. Swelling was not due to hypothermia because $9^{\circ} \mathrm{C}$ physiologic solution did not affect volume. Lowering the $\mathrm{KCl}$ product of St Thomas' Hospital solution by partially replacing $\mathrm{Cl}^{-}$with an impermeant anion prevented cellular edema in all groups. Conclusion: In the absence of ischemia, neonatal cells were more sensitive to cardioplegia-induced cellular edema than more mature cells, and edema observed in all groups was avoided by decreasing the $\mathrm{KCl}$ product of St Thomas' Hospital solution to the physiologic range. Differences in cell volume regulation may explain the sensitivity of neonatal hearts to hyperkalemic cardioplegic arrest and suggest novel approaches to improving myocardial protection. (J Thorac Cardiovasc Surg 1999;118:467-76)
T he principles of myocardial protection as outlined by Hearse $^{1}$ consist of 3 distinct components: (1) energy conservation via rapid and complete diastolic arrest; (2) deceleration of the metabolic rate; and (3) prevention or reversal of unfavorable ischemic changes. Unfortunately, an ideal cardioprotective solution that addresses all 3 of these criteria does not exist. In certain instances, current methods provide inadequate myocardial protection, and edema and myocardial dysfunction

From the Departments of Surgery (Division of Cardiothoracic Surgery), ${ }^{\mathrm{a}}$ Internal Medicine (Division of Cardiology), ${ }^{\mathrm{b}}$ and Physiology, ${ }^{c}$ Medical College of Virginia, Virginia Commonwealth University, Richmond, Va, and Section of Cardiothoracic Surgery, ${ }^{\mathrm{d}}$ The Milton S. Hershey Medical Center, Pennsylvania State University-Geisinger Health System, Hershey, Pa.

Supported by National Institutes of Health grants HL-09817 (J.S.D., C.M.B.) and HL-46764 (C.M.B.). continue to complicate the postoperative course after cardiac procedures. ${ }^{2-4}$ Although experimental evidence suggests that the immature heart is more tolerant of ischemic insults than the adult heart, ${ }^{5-7}$ current cardioplegic solutions have been found to be less effective in neonates. . $^{5,8,9}$

Myocardial edema after cardioplegic arrest has been implicated as an etiologic factor in various detrimental physiologic sequelae. Left ventricular function is depressed, ${ }^{2,4,10}$ the action potential is prolonged, ${ }^{11,12}$

Received for publication March 11, 1999; revisions requested April 30, 1999; revisions received May 18, 1999; accepted for publication May 18, 1999.

Address for reprints: Clive M. Baumgarten, PhD, Department of Physiology, Medical College of Virginia, Virginia Commonwealth University, Richmond, VA 23298-0551 (E-mail: baumgart@hsc.vcu.edu).

Copyright @ 1999 by Mosby, Inc.

0022-5223/99 $\$ 8.00+0 \quad \mathbf{1 2 / 1 / 1 0 0 2 7 9}$ 
and ventricular ectopy and arrhythmias occur. ${ }^{13}$ Furthermore, myocardial edema diminishes drug efficacy $^{14}$ and contributes to the "no-reflow" phenomenon. ${ }^{15}$

Ischemia, cardiopulmonary bypass, and the nature of the cardioplegic solution itself all have been hypothesized to contribute to the sequelae of cardioplegic arrest. To define the isolated effects of cardioplegia, we previously studied the effects of cardioplegic solution in the absence of ischemia and cardiopulmonary bypass on cell volume of isolated adult rabbit ${ }^{16,17}$ and human ${ }^{17}$ cardiomyocytes. Although St Thomas' Hospital solution is designed to be isosmotic, it is not always isotonic. Adult atrial and ventricular myocytes promptly swell on exposure to hypothermic St Thomas' Hospital solution, whereas myocyte volume is maintained when cells are cooled in solution with a more physiologic ionic composition. ${ }^{16,17}$ The hypothesis that swelling caused by the cardioplegic solution alone contributes to myocardial dysfunction has been supported by the fact that manipulations that prevent edema in the isolated adult myocyte markedly improved recovery of function after cardioplegic arrest in the working intact heart. ${ }^{12}$

Although the propensity for St Thomas' Hospital solution to cause cellular edema is well established in the adult, the implications for neonatal cell volume regulation are unclear. Characteristics of ion channels and transporters differ in immature and adult cells. ${ }^{18,19}$ Functionally, the neonatal heart is less compliant, has less diastolic reserve, and functions on a relatively flat Starling curve. ${ }^{20}$ Because of these differences, the consequences of cellular edema may be more severe in the immature heart than the adult heart.

Multiple studies have documented the adverse effects of cardioplegia on the neonatal heart during global ischemia. ${ }^{9}, 21-23$ The present results indicate that immature myocytes undergo profound swelling on exposure to St Thomas' Hospital solution in the absence of ischemia and cardiopulmonary bypass. This may contribute to the suboptimal results obtained clinically in the neonate. Guided by principles of cell volume regulation, we modified the ionic composition of $\mathrm{St}$ Thomas' Hospital solution and ameliorated its adverse effects on cell volume.

\section{Materials and methods}

Myocyte isolation. Isolated single ventricular cardiomyocytes were obtained from New Zealand White rabbits (either sex) at 3 different ages: (1) neonatal, 3 to 5 days of age; (2) intermediate, 10 to 13 days of age; and (3) adult, more than 6 weeks of age. All animals received humane care in accordance with the "Guide for the Care and Use of Laboratory Animals" prepared by the Institute of Laboratory Animal Resources and published by the National Academy Press (revised 1996). Rabbits were sedated (acepromazine maleate, $25 \mathrm{mg} / \mathrm{kg}$; xylazine, $5 \mathrm{mg} / \mathrm{kg}$ ), heparinized (neonatal and intermediate, $500 \mathrm{IU}$; adult, $1000 \mathrm{IU}$ ), and anesthetized (ketamine, $35 \mathrm{mg} / \mathrm{kg}$ ). A rapid cardiectomy was performed through a median sternotomy. The aorta was rapidly cannulated, and the heart was suspended and perfused in a retrograde fashion via a modified Langendorff perfusion system. Protocols to isolate adult ventricular cells with collagenase (1 $\mathrm{mg} / \mathrm{mL})$ and pronase $(0.1 \mathrm{mg} / \mathrm{mL})$ were previously described. ${ }^{16,24}$ These conditions were too caustic for neonatal and intermediate hearts, and the enzyme concentrations and duration of exposure were reduced to obtain high yields of calcium-tolerant cells. For intermediate and neonatal hearts, enzyme concentrations were reduced by a factor of 4 and 6 , respectively, and enzyme exposure was decreased from 10 to 5 minutes for both groups.

Volume measurements. An aliquot of myocytes was placed in a glass-bottom chamber and suprafused with $37^{\circ} \mathrm{C}$ physiologic Tyrode solution at a rate of 4.5 to $5.0 \mathrm{~mL} / \mathrm{min}$. Cells were allowed to equilibrate for at least 20 minutes before experimental interventions were applied. Methods for determining cell volume were previously described in detail. ${ }^{16,24}$ In brief, a high-resolution television camera (CCD72; Dage MTI, Michigan City, Ind) was mounted on an inverted microscope (Nikon Inc, Garden City, NY) equipped with Hoffman modulation optics (Hoffman Modulation Optics, Inc, Greenvale, NY) $(\times 40,0.55$ NA [numeric aperture]). Images were digitized on-line by a video frame-grabber (Targa-M8; Truevision, Indianapolis, Ind).

Cell volumes were assessed by methods developed in this laboratory. ${ }^{16,24}$ The resolution of digitization was $\sim 0.2$ $\mu \mathrm{m} /$ pixel. Cell borders were digitally traced with SigmaScan Pro software (SPSS, Inc, Chicago, Ill). This software also provided contrast enhancement and image magnification. Relative cell volume was estimated from the traced image with custom software.

Previous studies have shown that the width and thickness of isolated cardiomyocytes change proportionally in response to various volume perturbations. ${ }^{24}$ Therefore relative cell volume was determined as follows:

$$
\begin{aligned}
& \text { Volume }_{\text {test }} / \text { Volume }_{\text {control }}= \\
& \quad\left(\text { Area }_{\text {test }} \times \text { Width }_{\text {test }}\right) / \text { Area }_{\text {control }} \times \text { Width }_{\text {control }}
\end{aligned}
$$

Relative cell volume is independent of the assumed crosssectional shape of the myocyte so long as the geometry of the cross section does not change during the experiment. Estimates of cell volume are reproducible to less than $1 \%$ for adult cells. ${ }^{16,24}$ Intermediate and neonatal cells are smaller than adult myocytes, and their image comprises fewer pixels. On the basis of repeated measurements, we found estimates of cell volume were reproducible to within $2 \%$ for intermediate and $3 \%$ for neonatal cells.

Experimental protocol. Protocols consisted of sequential equilibration, experimental, and reperfusion periods, each 20 minutes in duration. Cells were allowed to equilibrate and were reperfused in normothermic $\left(37^{\circ} \mathrm{C}\right)$ physiologic Tyrode solution. To delineate the age-dependence of the response to 
cardioplegic solution temperature, cells were subjected to either normothermic or hypothermic $\left(9^{\circ} \mathrm{C}\right)$ St Thomas' Hospital solution. To identify effects of hypothermia alone, cells were suprafused with hypothermic Tyrode solution. Finally, to define mechanisms of cellular edema, 2 low- $\mathrm{Cl}^{-}$ variants of St Thomas' Hospital solution were tested. Images were obtained after 18 and 20 minutes of equilibration (control) and then at 5-minute intervals during the experimental and reperfusion periods.

Solutions. Modified Tyrode solution (osmolarity $=297 \pm 2$ mOsm; $\left[\mathrm{K}^{+}\right]\left[\mathrm{Cl}^{-}\right]$product $=700 \mathrm{mmol}^{2} / \mathrm{L}^{2}$ ) contained (in millimoles per liter): $130 \mathrm{NaCl}, 5 \mathrm{KCl}, 2 \mathrm{MgSO}_{4}, 10$ glucose, and 5 HEPES titrated to $\mathrm{pH} 7.4$ with $\mathrm{NaOH}$. Standard St Thomas' Hospital solution (osmolarity = $303 \pm 4 \mathrm{mOsm}$; $\left[\mathrm{K}^{+}\right]\left[\mathrm{Cl}^{-}\right]$product $=2566.4 \mathrm{mmol}^{2} / \mathrm{L}^{2}$ ) contained (in millimoles per liter): $110 \mathrm{NaCl}, 10 \mathrm{NaHCO}_{3}, 16 \mathrm{MgCl}_{2}, 16 \mathrm{KCl}$ and $1.2 \mathrm{CaCl}_{2}$. To decrease the $\left[\mathrm{K}^{+}\right]\left[\mathrm{Cl}^{-}\right]$product of standard St Thomas' Hospital solution $\left(\left[\mathrm{Cl}^{-}\right]=160.4 \mathrm{mmol} / \mathrm{L}\right), \mathrm{Cl}^{-}$was partially replaced by equimolar concentrations of methanesulfonate, an impermeant anion. This low-Cl variant of $\mathrm{St}$ Thomas' Hospital solution $\left(\mathrm{Cl}_{44} \mathrm{STS}\right.$ ) contained (in millimoles per liter): $110 \mathrm{Na}$-methanesulfonate, $10 \mathrm{NaHCO}_{3} 16 \mathrm{MgCl}_{2}$, $9.35 \mathrm{KCl}, 6.65 \mathrm{~K}$-methanesulfonate, and $1.2 \mathrm{CaCl}_{2}$ (osmolarity $=304 \pm 2 \mathrm{mOsm} ;\left[\mathrm{K}^{+}\right]\left[\mathrm{Cl}^{-}\right]$product $=700 \mathrm{mmol}^{2} / \mathrm{L}^{2} ;\left[\mathrm{Cl}^{-}\right]$ $=43.75 \mathrm{mmol} / \mathrm{L})$. In a second lower $\mathrm{Cl}^{-}$variant $\left(\mathrm{Cl}_{34} \mathrm{STS}\right)$, the remaining $9.35 \mathrm{mmol} / \mathrm{L} \mathrm{KCl}$ was replaced with $\mathrm{K}$-methanesulfonate $\left(\right.$ osmolarity $=298 \pm 2 \mathrm{mOsm} ;\left[\mathrm{K}^{+}\right]\left[\mathrm{Cl}^{-}\right]$product $=$ $\left.550.4 \mathrm{mmol}^{2} / \mathrm{L}^{2},\left[\mathrm{Cl}^{-}\right]=34.4 \mathrm{mmol} / \mathrm{L}\right)$. All variants of $\mathrm{St}$ Thomas' Hospital solution were bubbled with $95 \%$ oxygen and $5 \%$ carbon dioxide and adjusted to $\mathrm{pH}$ 7.4.

Statistical analysis. Results are expressed as mean \pm standard error. All statistical calculations were performed in SigmaStat 2.0 software (SPSS, Inc, Chicago, Ill). A 1-way repeated-measures analysis of variance was used for sequential, time-based measurements. Treatment significance was evaluated by an F-ratio test, and individual treatment means were compared with control values by Dunnett's test. Analysis of variance and Tukey's test were used to compare age groups. For the comparison of absolute volume between age groups, a log transform was used to equalize the variance of the groups because variance was a function of the age group mean.

\section{Results}

Control morphology. The measured dimensions of length and width among the 3 groups of cells after equilibration in normothermic, physiologic Tyrode solution were significantly different. Baseline length and width for neonatal cells were $72.6 \pm 2.3 \mu \mathrm{m}$ and 8.9 $\pm 0.2 \mu \mathrm{m}(\mathrm{n}=43)$, respectively, as compared with 88.3 $\pm 2.4 \mu \mathrm{m}$ and $10.4 \pm 0.3 \mu \mathrm{m}$ for intermediate cells $(\mathrm{n}=$ 42) and $152.9 \pm 2.9 \mu \mathrm{m}$ and $20.1 \pm 0.5 \mu \mathrm{m}$ for adult cells $(n=47)$. Absolute volumes of myocytes were estimated assuming equal width and thickness. ${ }^{16,24}$ On the basis of this assumption, the calculated volumes were
$5.9 \pm 0.3 \mathrm{pL}(\mathrm{n}=43)$ for neonatal cells, $10.1 \pm 0.8 \mathrm{pL}$ $(\mathrm{n}=42)$ for intermediate cells, and $64.6 \pm 3.6 \mathrm{pL}(\mathrm{n}=$ 47) for adult cells. Significant differences in the calculated volumes were noted among all age groups. If cylindrical geometry was assumed instead, the estimated volumes would be reduced by a factor of 0.785 $(4 / \pi)$. To eliminate uncertainty related to any agedependent difference in cross-sectional morphology, we have presented the remaining volume data as percent change of relative cell volume with each cell as its own control.

The effect of normothermic St Thomas' Hospital solution on relative cell volume. Although St Thomas' Hospital solution is isosmotic $(\sim 300 \mathrm{mOsm} / \mathrm{L})$, its effect on cell volume (ie, tonicity) depends on properties of the sarcolemma, which may be age- and temperature-dependent. Neonatal cells $(n=8)$ swelled during suprafusion with normothermic St Thomas' Hospital solution (Fig 1, A). After 5 minutes, the relative cell volume of neonatal myocytes increased by $12.7 \% \pm 2.1 \%$ $(P<.01)$ and further increased to $16.2 \% \pm 1.8 \%(P<$ $.01)$ after 20 minutes. On reperfusion with isosmotic physiologic Tyrode solution, cell volume returned to its control value within 5 minutes and remained constant throughout the 20-minute reperfusion period. In contrast, normothermic St Thomas' Hospital solution did not significantly alter the volume of intermediate (Fig 1, $B, \mathrm{n}=7 ; P=.5$ ) or adult (Fig 1, $C, \mathrm{n}=12 ; P=.9$ ) cells. After 20 minutes of suprafusion with normothermic St Thomas' Hospital solution, neonatal cells were significantly more swollen than both their intermediate and adult counterparts. There was no significant difference in myocyte volume among the groups after 20 minutes of normothermic reperfusion with physiologic Tyrode solution.

The effect of cold St Thomas' Hospital solution on relative cell volume. The age-dependent response to $\mathrm{St}$ Thomas' Hospital solution was altered by temperature (Fig 2). To simulate hypothermic conditions often used in the clinical setting, myocytes were exposed to $9^{\circ} \mathrm{C} \mathrm{St}$ Thomas' Hospital solution. Neonatal cells (Fig 2, A, $\mathrm{n}=$ 10) swelled $10.5 \% \pm 1.8 \%(P<.01)$ after 5 minutes, and cellular edema increased to $16.8 \% \pm 1.5 \%(P<.01)$ at 20 minutes. In contrast to findings under normothermic conditions, neonatal cells remained edematous on reperfusion with normothermic Tyrode solution. Volume was $13.9 \% \pm 1.9 \%$ greater than control $(P<.01)$ after 5 minutes and remained elevated by $8.1 \% \pm 1.5 \%(P<.01)$ after 20 minutes. Intermediate cells (Fig 2, $B, \mathrm{n}=11$ ) also swelled significantly on exposure to cold St Thomas' Hospital solution. Cell volume was $7.0 \% \pm$ $1.8 \%$ greater than control $(P<.01)$ after 5 minutes, and 

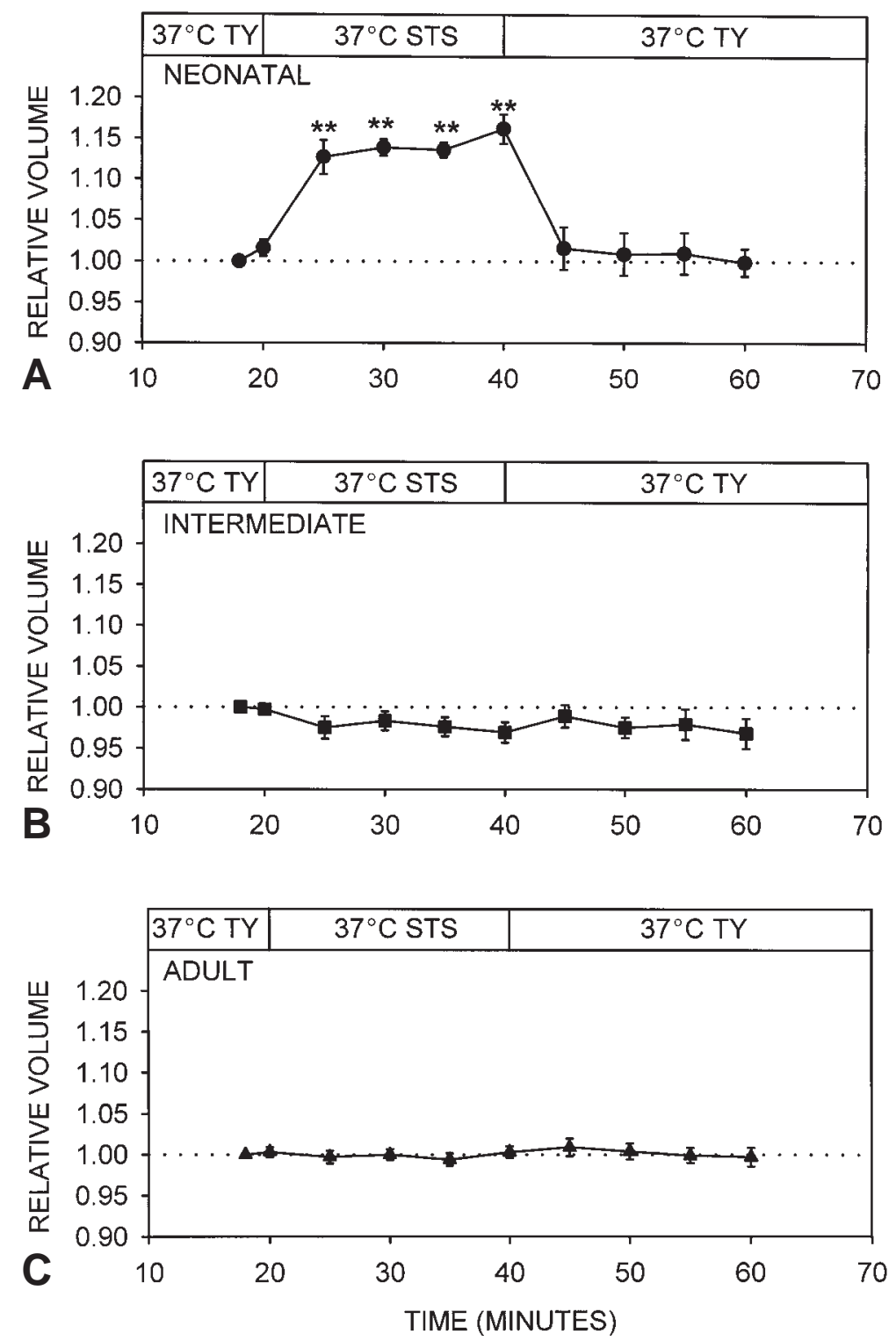

Fig 1. Relative cell volume of $(\mathbf{A})$ neonatal $(n=8),(\mathbf{B})$ intermediate $(n=7)$, and $(\mathbf{C})$ adult $(\mathrm{n}=12)$ cardiomyocytes during 20-minute exposures to $37^{\circ} \mathrm{C}$ St Thomas' Hospital solution (STS) and 20 minutes of reperfusion in $37^{\circ} \mathrm{C}$ physiologic Tyrode solution $(T Y)$. Volumes during the interventions are compared with those of the same myocyte after initial equilibration in Tyrode solution. Neonatal cells significantly swelled during suprafusion with $37^{\circ} \mathrm{C}$ St Thomas' Hospital solution, and cell volume returned to control values on reperfusion with $37^{\circ} \mathrm{C}$ Tyrode solution. In contrast, the volumes of intermediate and adult cells were not affected by $37^{\circ} \mathrm{C}$ St Thomas' Hospital solution or reperfusion. Significant $\left({ }^{* *} \mathrm{P}<.01\right)$ when compared with control volume in $37^{\circ} \mathrm{C}$ Tyrode solution.

swelling further increased to $8.6 \% \pm 2.1 \%(P<.01)$ over control after 20 minutes. Intermediate cells eventually recovered fully during reperfusion, but their volume remained significantly above control values at 5 and 15 minutes. Adult cells also swelled when subjected to cold St Thomas' Hospital solution (Fig 2, $C, \mathrm{n}=13$ ). These cells had $5.3 \% \pm 0.8 \%(P<.01)$ and $5.6 \% \pm 1.1 \%(P<$
.01 ) increases in volume after 5 and 20 minutes, respectively. In contrast to the neonate and intermediate groups, which failed to recover or only slowly recovered during reperfusion, the volume of adult cells promptly returned to the control level and then decreased by $3.6 \%$ $\pm 1.2 \%(P<.05)$ after 10 minutes and $3.5 \% \pm 1.5 \%$ ( $P$ $<.05)$ after 20 minutes. These results were similar to 

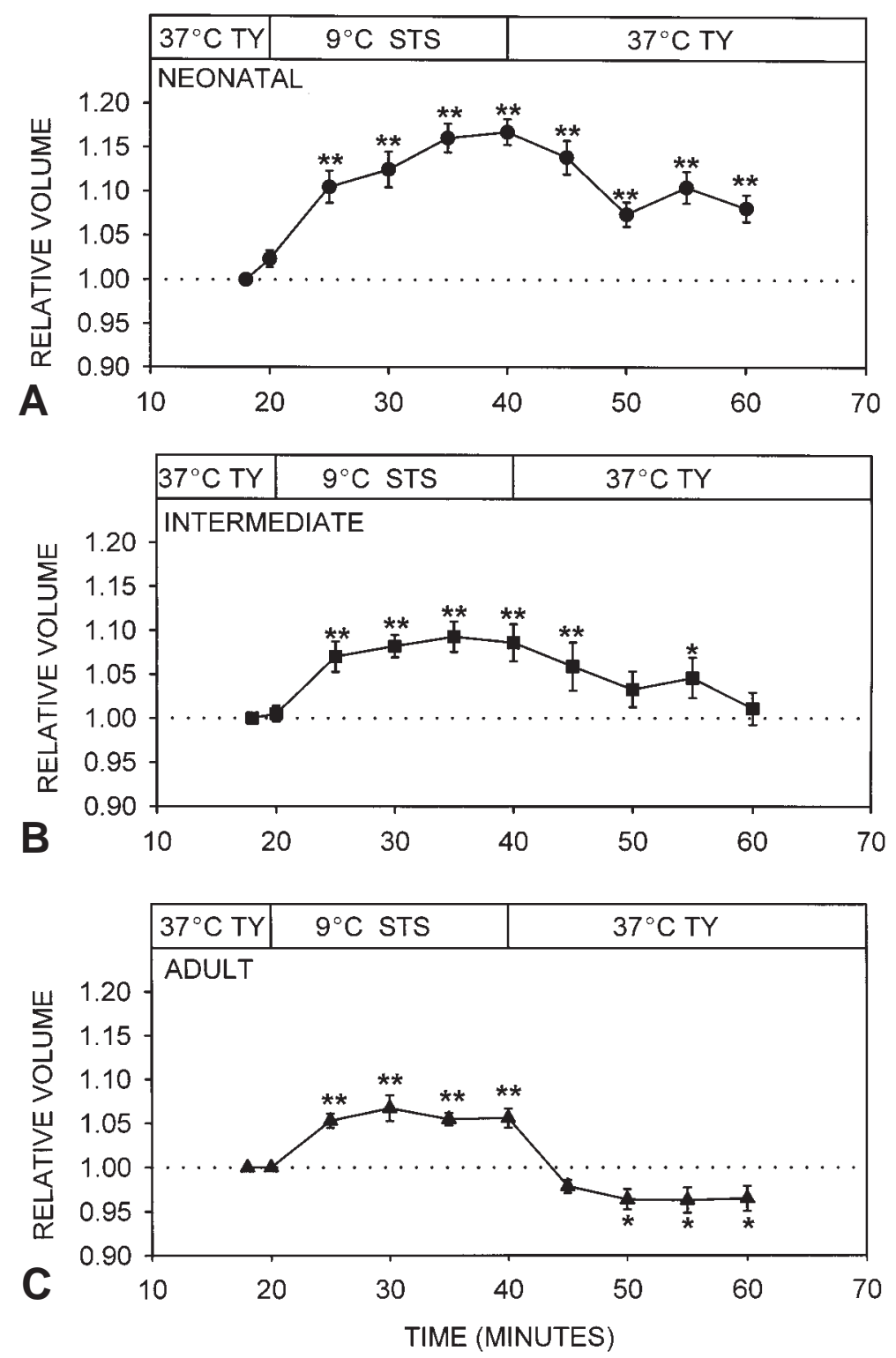

Fig 2. Relative cell volume of $(\mathbf{A})$ neonatal $(\mathrm{n}=10)$, $(\mathbf{B})$ intermediate $(\mathrm{n}=11)$, and $(\mathbf{C})$ adult $(\mathrm{n}=13)$ cardiomyocytes during 20-minute exposures to $9^{\circ} \mathrm{C}$ St Thomas' Hospital solution (STS) and 20 minutes of reperfusion in $37^{\circ} \mathrm{C}$ physiologic Tyrode solution (TY). Neonatal cells significantly swelled during suprafusion with $9^{\circ} \mathrm{C}$ St Thomas' Hospital solution and remained edematous throughout 20 minutes of reperfusion with $37^{\circ} \mathrm{C}$ Tyrode solution. Intermediate and adult cells also swelled in $9^{\circ} \mathrm{C}$ St Thomas' Hospital solution. During reperfusion, the volume of intermediate cells returned to baseline and that of adult cells decreased slightly below initial values. Significant $\left({ }^{*} P\right.$ $<.05$; $\left.{ }^{* *} P<.01\right)$ when compared with control volume in $37^{\circ} \mathrm{C}$ Tyrode solution within age groups. In comparisons between age groups, the volume of neonatal cells was significantly $(P<.01)$ greater than those of intermediate and adult cells both after 20 minutes in $9^{\circ} \mathrm{C}$ St Thomas' Hospital solution and after 20 minutes of reperfusion.

previous studies on rabbit atrial ${ }^{17}$ and ventricular ${ }^{16}$ myocytes and human atrial ${ }^{17}$ myocytes.

The effect of hypothermia alone on relative cell volume. Previous studies on adult cells ${ }^{16,17}$ concluded that swelling in hypothermic St Thomas' Hospital solution was due to the composition of the cardioplegic solution rather than hypothermia because adult atrial and ventricular myocytes do not swell during 20 min- 

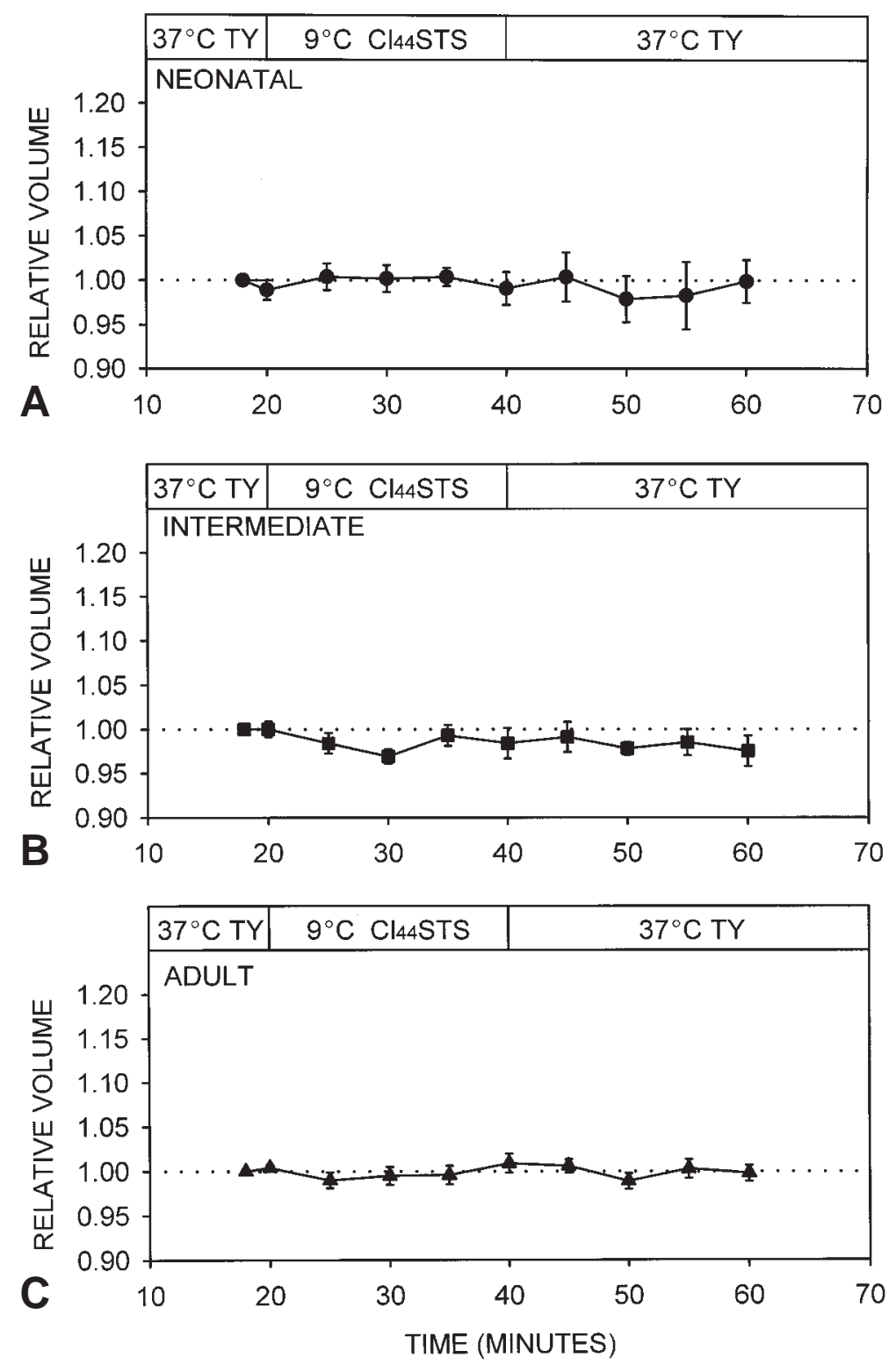

Fig 3. Relative cell volume of $(\mathbf{A})$ neonatal $(n=7)$, $(\mathbf{B})$ intermediate $(n=7)$, and $(\mathbf{C})$ adult $(n=11)$ cardiomyocytes during 20-minute exposures to $9^{\circ} \mathrm{C}_{\text {low- }} \mathrm{Cl}^{-}$St Thomas' Hospital solution containing $43.75 \mathrm{mmol} / \mathrm{L} \mathrm{Cl}^{-}$ $\left(C l_{44} S T S\right)$ and 20 minutes of reperfusion in $37^{\circ} \mathrm{C}$ Tyrode solution $(T Y)$. Lowering the $\left[\mathrm{K}^{+}\right]\left[\mathrm{Cl}^{-}\right]$product to that of physiologic solution $\left(700 \mathrm{mmol}^{2} / \mathrm{L}^{2}\right)$ negated the intrinsic edematous properties of St Thomas' Hospital solution. There was no significant difference in the relative volumes of any age group during the $\mathrm{Cl}_{44} \mathrm{STS}$ suprafusion or reperfusion.

utes of exposure to $9^{\circ} \mathrm{C}$ Tyrode solution. Analogous experiments revealed that the volumes of neither neonatal $(\mathrm{n}=7, P=.5)$ nor intermediate $(\mathrm{n}=6, P>.9)$ cells were significantly altered after a 20 -minute exposure to hypothermic Tyrode solution.

Prevention of cardiomyocyte edema with low- $\mathrm{Cl}^{-}$ St Thomas' Hospital solution. We previously demon- strated that the volume of adult myocytes was regulated by Donnan equilibrium under hypothermic conditions. ${ }^{16,17}$ This implies that the $\left[\mathrm{K}^{+}\right]\left[\mathrm{Cl}^{-}\right]$product of cardioplegic solution controls cell volume. Reducing the $\left[\mathrm{K}^{+}\right]\left[\mathrm{Cl}^{-}\right]$product of standard St Thomas' Hospital solution from 2655.4 to $700 \mathrm{mmol}^{2} / \mathrm{L}^{2}$, the same as in physiologic Tyrode solution, was shown to prevent cel- 

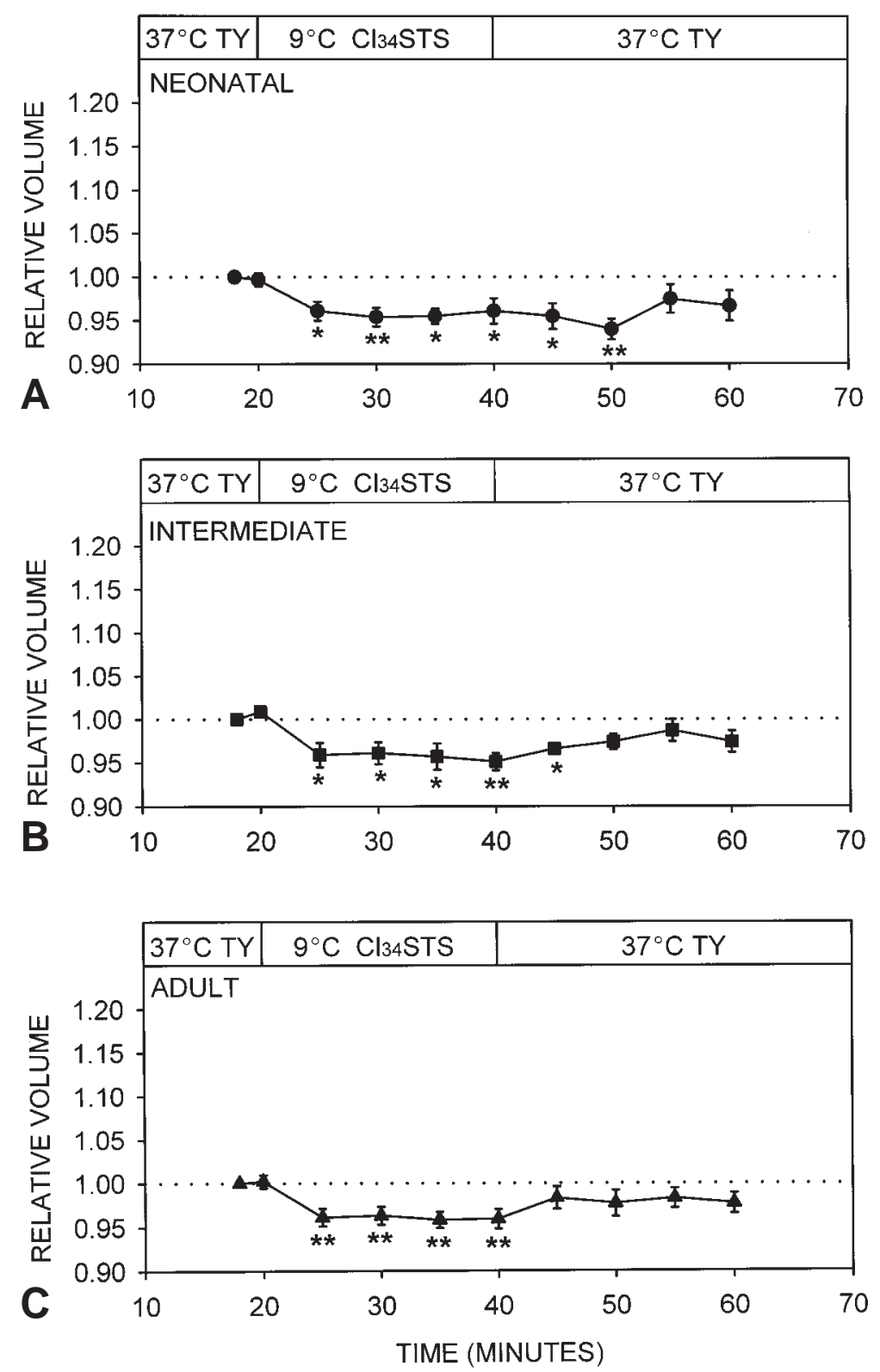

Fig 4. Relative cell volume of $(\mathbf{A})$ neonatal $(n=11),(\mathbf{B})$ intermediate $(n=11)$, and $(\mathbf{C})$ adult $(n=11)$ cardiomyocytes during 20-minute exposures to $9^{\circ} \mathrm{C}$ low- $\mathrm{Cl}^{-}$St Thomas' Hospital solution containing a $34.4 \mathrm{mmol} / \mathrm{L}$ concentration of $\mathrm{Cl}^{-}\left(\mathrm{Cl}_{34} \mathrm{STS}\right)$ and 20 minutes of reperfusion in $37^{\circ} \mathrm{C}$ Tyrode solution (TY). The volume of neonatal cells significantly contracted in $9^{\circ} \mathrm{C} \mathrm{Cl}_{34} \mathrm{STS}$ and remained contracted throughout the first 10 minutes of reperfusion with $37^{\circ} \mathrm{C}$ Tyrode solution. The volume of intermediate and adult cells also contacted in $9^{\circ} \mathrm{C} \mathrm{Cl}_{34} \mathrm{STS}$. During reperfusion, the volume of intermediate cells returned to baseline after 5 minutes. Adult cells returned to baseline before 5 minutes. Significant $\left({ }^{*} P<.05 ;{ }^{* *} P<.01\right)$ when compared with control volume in $37^{\circ} \mathrm{C}$ Tyrode solution.

lular edema in adult myocytes in cold St Thomas' Hospital solution. ${ }^{16,17}$

Fig 3 demonstrates that volume regulation in neonatal and intermediate myocytes was as expected for cells governed by a Donnan equilibrium and confirmed our previous findings for adult cells. When the $\left[\mathrm{K}^{+}\right]\left[\mathrm{Cl}^{-}\right]$ product of standard St Thomas' Hospital solution was decreased from $2566.4 \mathrm{mmol}^{2} / \mathrm{L}^{2}$ to $700 \mathrm{mmol}^{2} / \mathrm{L}^{2}$ by replacing $\mathrm{Cl}^{-}$with an impermeant anion $\left(\mathrm{Cl}_{44} \mathrm{STS}\right)$, myocytes maintained a constant volume at $9^{\circ} \mathrm{C}$ and 
during normothermic reperfusion (Fig 3, A, neonatal, n $=7, P>.9 ;$ Fig $3, B$, intermediate, $\mathrm{n}=7, P=.7$; Fig 3, $C$, adult, $\mathrm{n}=11, P=.7)$. Thus lowering the $\left[\mathrm{K}^{+}\right]\left[\mathrm{Cl}^{-}\right]$ product of St Thomas' Hospital solution converted it from a hypotonic to an isotonic solution under hypothermic conditions for all age groups.

Donnan theory predicts that lowering the $\left[\mathrm{K}^{+}\right]\left[\mathrm{Cl}^{-}\right]$ product of St Thomas' Hospital solution to a value below that of physiologic bathing solution should decrease cell volume. To test this prediction, cells were suprafused with hypothermic St Thomas' Hospital solution in which $\mathrm{Cl}^{-}$was decreased to $34.4 \mathrm{mmol} / \mathrm{L}$, and the $\left[\mathrm{K}^{+}\right]\left[\mathrm{Cl}^{-}\right]$product was $550.4 \mathrm{mmol}^{2} / \mathrm{L}^{2}$ $\left(\mathrm{Cl}_{34} \mathrm{STS}\right)$. The volume of neonatal cells (Fig $4, A, \mathrm{n}=$ 11) decreased by a maximum of $4.5 \% \pm 0.9 \%(P<.01)$ in hypothermic $\mathrm{Cl}_{34}$ STS. The volume of neonatal cells remained significantly contracted after 5 and 10 minutes of reperfusion $(4.5 \% \pm 1.5 \%, 6.0 \% \pm 1.2 \%$, respectively) and then tended toward baseline. Although recovery was not complete, the volumes at 15 and 20 minutes of reperfusion were not significantly different from control. Intermediate (Fig 4, $B, \mathrm{n}=11$ ) and adult cells (Fig 4, $C, \mathrm{n}=11$ ) also demonstrated a relative volume decrease while being suprafused with hypothermic $\mathrm{Cl}_{34}$ STS. The volumes of intermediate and adult cells contracted by $4.9 \% \pm 1.0 \%(P<.01)$ and $4.1 \% \pm 1.1 \%(P<.01)$, respectively, after 20 minutes. Although the extent of volume contraction in $\mathrm{Cl}_{34}$ STS was similar for each age group, during reperfusion the volume of intermediate and adult cells recovered to a value indistinguishable from control more rapidly than neonatal cells (10 and 5 minutes vs 15 minutes). Findings that a solution with a lower than physiologic $\left[\mathrm{K}^{+}\right]\left[\mathrm{Cl}^{-}\right]$product reduces cell volume confirm that volume is regulated according to Donnan equilibrium and may have implications for other cardioplegic solutions, such as University of Wisconsin solution, in which the $\left[\mathrm{K}^{+}\right]\left[\mathrm{Cl}^{-}\right]$product is much lower than physiologic values.

\section{Discussion}

The osmolarity of a solution depends on the number of osmotically active particles it contains. In contrast, tonicity also takes into account cell membrane properties and reflects cellular volume changes in response to the composition of the solution. Despite the fact that $\mathrm{St}$ Thomas' Hospital solution is designed to be isosmotic, the present study demonstrates that its tonicity depends on myocyte maturity and the solution temperature. In the absence of ischemia, we have demonstrated that isolated neonatal cardiomyocytes respond differently to St Thomas' Hospital solution than adult cells. Neonatal cells suprafused with St Thomas' Hospital solution developed cellular edema under both normothermic and hypothermic conditions, whereas more mature cells swelled only in hypothermic solutions. Moreover, the degree of swelling was significantly greater in neonatal cells than in more mature cells. Finally, swelling in cold St Thomas' Hospital solution was not due to hypothermia alone, as exposure to a hypothermic physiologic solution did not affect cell volume.

$\mathrm{We}^{16,17}$ previously suggested that under hypothermic conditions adult heart cells regulate their volume by Donnan equilibrium. In a Donnan system, the equilibrium potentials for $\mathrm{K}^{+}$and $\mathrm{Cl}^{-}$are equal and the products of the concentrations of these 2 ions $\left(\left[\mathrm{K}^{+}\right]\left[\mathrm{Cl}^{-}\right]\right)$ are equal on both sides of the membrane. Subjecting the myocyte to an isosmotic solution with an elevated $\left[\mathrm{K}^{+}\right]\left[\mathrm{Cl}^{-}\right]$product will cause these ions to flow down their electrochemical gradients, resulting in an increase of $\mathrm{K}^{+}$and $\mathrm{Cl}^{-}$within the cell. Water passively follows this redistribution of ions leading to cellular edema. Despite having nearly identical osmolarities, St Thomas' Hospital solution has more than a 3-fold greater $\left[\mathrm{K}^{+}\right]\left[\mathrm{Cl}^{-}\right]$product $\left(2566.4 \mathrm{mmol}^{2} / \mathrm{L}^{2}\right)$ than Tyrode's solution $\left(700 \mathrm{mmol}^{2} / \mathrm{L}^{2}\right)$. Consequently, St Thomas' Hospital solution is hypotonic despite being isosmotic and induces edema in cells regulated by Donnan equilibrium, such as adult cardiomyocytes under hypothermic conditions. ${ }^{16,17}$

The observed cell swelling with exposure to both hypothermic and normothermic St Thomas' Hospital solution means that this solution is hypotonic for neonatal cells despite being isosmotic. This is consistent with the hypothesis that the volume of neonatal myocytes is governed by Donnan equilibrium under both normothermic and hypothermic conditions. In contrast, the volume of more mature cells is regulated in this manner only during hypothermia, ${ }^{16,17}$ indicating that other regulatory mechanisms are operational at physiologic temperatures. The extent of swelling in standard St Thomas' Hospital solution also was agedependent. Neonatal cells swelled significantly more than more mature cells. Perhaps a more important clinical concern is that only neonatal cells remained edematous during normothermic reperfusion. One possible explanation is that the swelling of neonatal cells may be sufficient to cause irreversible damage, whereas the more modest swelling of more mature cells may not compromise their ability to regulate cell volume.

The demonstration that judicious adjustment of the $\left[\mathrm{K}^{+}\right]\left[\mathrm{Cl}^{-}\right]$product of cardioplegic solution by partially replacing $\mathrm{Cl}^{-}$with an impermeant anion averts spontaneous swelling of myocytes under hypothermic conditions suggests a novel approach to improve cardiopro- 
tection. Cardioplegic solutions designed for hypothermic application need to consider both the osmolarity and the $\left[\mathrm{K}^{+}\right]\left[\mathrm{Cl}^{-}\right]$product of the formulation, and it is possible to match the $\left[\mathrm{K}^{+}\right]\left[\mathrm{Cl}^{-}\right]$product of cardioplegic solution to that of the patient's plasma. Reducing the $\left[\mathrm{K}^{+}\right]\left[\mathrm{Cl}^{-}\right]$product of St Thomas' Hospital solution to make the solution isotonic as well as isosmotic improved functional recovery after cardioplegic arrest in the working rabbit heart. ${ }^{12}$ Replacement of $\mathrm{Cl}^{-}$by an impermeant anion is critical for cell volume regulation, but there is no evidence that $\mathrm{Cl}^{-}$itself is detrimental.

Several ontological differences may partially account for the present findings. The most obvious explanation for age-dependent volume regulation and differential responses to cardioplegic solutions lies in the differential expression and density of various ion channels and transporters and their relative sensitivity to alterations in temperature. Although the physiology of membrane protein development has not been fully defined, agedependent changes in ion transport and regulation are widely known. ${ }^{8,18,19,25,26}$ Furthermore, neonatal cells possess a greater surface/volume ratio than adult cells, ${ }^{27}$ which magnifies the effect of disparities in ion fluxes on cell volume. Finally, neonatal cells may be more compliant than adult cells and therefore respond to increased water influx with greater volume changes than the less compliant adult myocyte. This is unlikely to be a significant mechanism because the forces developed within myocytes are small compared with the effective osmotic pressure gradient necessary to explain the observed swelling. ${ }^{28}$

Clinical implications. Myocardial edema adversely affects cardiac conduction, ${ }^{11-13}$ left ventricular performance, ${ }^{4,10-12}$ and diastolic perfusion. ${ }^{15}$ The neonatal myocyte has a greater propensity for cellular edema during cardioprotection under both hypothermic and normothermic conditions than the adult. Furthermore, the immature heart already exists in a compromised state with limited diastolic reserve and less compliance than the mature heart. ${ }^{20}$ Therefore factors that contribute to cellular edema would be expected to have a greater impact on the global function of the immature heart, and measures directed at optimizing cellular volume might be expected to decrease perioperative morbidity.

In its current formulation, St Thomas' Hospital solution is not the ideal cardioprotective agent for use in the neonate because it is intrinsically hypotonic and produces cellular edema in a model that excludes the confounding contributions of cardiopulmonary bypass and ischemia to cellular edema. Several questions are raised by the present study that warrant further investigation. Although a low- $\mathrm{Cl}^{-}$variant of St Thomas'
Hospital solution improved functional recovery after global ischemia in adult rabbits, ${ }^{12}$ its predicted benefits for functional recovery in the intact neonatal heart need to be verified.

The present study examined only one facet of the cellular edema associated with cardioplegia, the intrinsic effects of St Thomas' Hospital solution alone. Ischemia and bypass during cardiac surgery also must be considered to fully understand the basis for cellular edema in the clinical setting. Moreover, these complex factors are likely to interact with the intrinsic tonicity of cardioplegic solution in determining the extent of edema. Isolated cardiomyocytes were used in this study to precisely follow cellular volume changes. However, one must be cautious in extrapolating data from the isolated myocyte to the intact heart. Isolated myocyte studies obscure the complex interactions between myocytes and fibroblasts, connective tissue, endothelial cells, and neural elements and their contributions to cardiac function. The effect of these other tissue components on myocyte volume regulation is unknown. In addition, the use of isolated myocyte disrupts the geometry of extracellular compartments. In the intact heart, the transport of water and ions among myocytes and the extracellular and vascular compartments contributes to the osmotic gradients established and the amount of cellular edema that occurs. Finally, the myocytes used in the present study were isolated from normal hearts. The majority of the hearts seen in the clinical setting possess elements of cyanosis, hypertrophy, or other disease processes. Recently, difference in cell volume regulation have been noted in myocytes isolated from an experimental dilated cardiomyopathy model. ${ }^{29}$ Future studies that focus on the effect of cardioplegic solutions on volume regulation in the diseased and intact heart are necessary.

We thank Alex J. Young for technical support and Luke G. Wolfe for statistical consultation.

\section{REFERENCES}

1. Hearse DJ. Cardioplegia: The protection of the myocardium during open heart surgery—a review. J Physiol (Paris) 1980;76:751-68.

2. Roberts AJ, Spies SM, Sanders JH, et al. Serial assessment of left ventricular performance following coronary artery bypass grafting: early postoperative results with myocardial protection afforded by multidose hypothermic potassium crystalloid cardioplegia. J Thorac Cardiovasc Surg 1981;81:69-84.

3. Handy JR, Dorman BH, Cavallo MJ, et al. Direct effects of oxygenated crystalloid or blood cardioplegia on isolated myocyte contractile function. J Thorac Cardiovasc Surg 1996;112:106472.

4. Weng ZC, Nicolosi AC, Detwiler PW, et al. Effects of crystalloid, blood, and University of Wisconsin perfusates on weight, water 
content, and left ventricular compliance in an edema-prone isolated porcine heart model. J Thorac Cardiovasc Surg 1992;103: 504-13.

5. Bove EL, Gallagher KP, Drake DH, et al. The effect of hypothermic ischemia on recovery of left ventricular function and preload reserve in the neonatal heart. J Thorac Cardiovasc Surg 1988;95: 814-8.

6. Grice WN, Konishi T, Apstein CS. Resistance of neonatal myocardium to injury during normothermic and hypothermic ischemic arrest and reperfusion. Circulation 1987;76(Suppl):V150-5.

7. Murphy CE, Salter DR, Morris JJ, et al. Age-related differences in adenine nucleotide metabolism during in vivo global ischemia. Surg Forum 1986;37:288-90.

8. Castaneda AR, Jonas RA, Mayer JE, Hanley FL. Myocardial preservation in the immature heart. In: Castaneda AR, Jonas RA, Mayer JE, Hanley FL, editors. Cardiac surgery of the neonate and infant. Philadelphia: WB Sanders; 1994. p. 41-51.

9. Bull C, Cooper J, Stark J. Cardioplegic protection of the child's heart. J Thorac Cardiovasc Surg 1984;88:287-93.

10. Hsu DT, Weng ZC, Nicolosi AC, Detwiler PW, Sciacca R, Spotnitz HM. Quantitative effects of myocardial edema on the left ventricular pressure-volume relation: influence of cardioplegia osmolarity over two hours of ischemic arrest. J Thorac Cardiovasc Surg 1993;106:651-7.

11. Cohen NM, Allen CA, Belz MK, Nixon TE, Wise RM, Damiano RJ Jr. Electrophysiological consequences of hypothermic hyperkalemic elective cardiac arrest. J Thorac Cardiovasc Surg 1993; 8:156-60

12. Jayawant AM, Stephenson ER, Baumgarten CM, Damiano RJ Jr. Prevention of cell swelling with low chloride St. Thomas Hospital solution improves postischemic myocardial recovery. J Thorac Cardiovasc Surg 1998;115:1196-202.

13. Cohen NM, Allen CA, Hsia PW, Nixon TE, Wise RM, Damiano RJ Jr. Electrophysiologic consequences of hyperkalemic cardioplegia during surgical ischemia. Ann Thorac Surg 1994;57:1076-83.

14. Wright AR, Rees SA. Cardiac cell volume: Crystal clear or murky waters? A comparison with other cell types. Pharmacol Ther 1998;80:89-121.

15. Powers ER, DiBona DR, Powell WJ Jr. Myocardial cell volume and coronary resistance during diminished coronary perfusion. Am J Physiol 1984;247:H467-77.

16. Drewnowska K, Clemo HF, Baumgarten CM. Prevention of myocardial intracellular edema induced by St. Thomas Hospital cardioplegic solution. J Mol Cell Cardiol 1991;23:1215-21.

17. Shaffer RF, Baumgarten CM, Damiano RJ Jr. Prevention of cel- lular edema directly caused by hypothermic cardioplegia: studies in isolated human and rabbit atrial myocytes. J Thorac Cardiovasc Surg 1998;115:1189-95.

18. Wang L, Feng ZP, Kondo CS, Sheldon RS, Duff HJ. Developmental changes in the delayed rectifier $\mathrm{K}^{+}$channels in mouse heart. Circ Res 1996;79:79-85.

19. Kato Y, Masumiya H, Agata N, Tanaka H, Shigenobu K. Developmental changes in action potential and membrane currents in fetal, neonatal and adult guinea-pig ventricular myocytes. J Mol Cell Cardiol 1996;28:1515-22.

20. Billingsley A, Laks H, Haas G. Myocardial protection in children. In: Baue A, Geha A, Hammond G, et al, editors. Glenn's thoracic and cardiovascular surgery. East Norwalk (CT): Appleton and Lange; 1991. p. 915-24.

21. Aoki M, Nomura F, Mayer JE Jr. Interactions between preischemic hypothermia and cardioplegic solutions in the neonatal lamb heart. J Thorac Cardiovasc Surg 1994;107:822-8.

22. Sawa Y, Matsuda H, Shimazaki Y, et al. Ultrastructural assessment of the infant myocardium receiving crystalloid cardioplegia. Circulation 1987;76(Suppl):V 141-5.

23. Murashita T, Borgers M, Hearse DJ. Developmental changes in tolerance to ischemia in the rabbit heart: disparity between interpretations of structural, enzymatic and functional indices of injury. J Mol Cell Cardiol 1992;24:1143-54.

24. Clemo HF, Baumgarten CM. Atrial natriuretic factor decreases cell volume of rabbit atrial and ventricular myocytes. Am J Physiol 1991;260:C681-90

25. Anderson PA. Immature myocardium. In: Moller JH, Neal WA, editors. Fetal, neonatal and infant cardiac disease. Norwalk (CT): Appleton and Lange; 1990. p. 35-71.

26. Touyz RM, Fareh J, Thibault G, Tolloczko B, Lariviere R, Schiffrin EL. Modulation of $\mathrm{Ca}^{2+}$ transients in neonatal and adult rat cardiomyocytes by angiotensin II and endothelin-1. Am J Physiol 1996;270:H857-68.

27. Page E, Earley J, Power B. Normal growth of ultrastructures in rat left ventricular myocardial cells. Circ Res 1974;35(Suppl): II12-6.

28. Baumgarten CM, Feher JJ. Osmosis and the regulation of cell volume. In: Sperelakis N, editor. Cell physiology source book. 2nd ed. New York: Academic Press; 1998. p. 253-92.

29. Clemo HF, Stambler BS, Baumgarten CM. Swelling-activated chloride current is persistently activated in ventricular myocytes from dogs with tachycardia-induced congestive heart failure. Circ Res 1999;84:157-65. 